\title{
Mucosal Melanoma of the Head and Neck pNO TNM Finding v8
}

National Cancer Institute

\section{Source}

National Cancer Institute. Mucosal Melanoma of the Head and NeckpNO TNM Finding v8. NCI Thesaurus. Code C133184.

Mucosal melanoma of the head and neck with no metastases to regional lymph nodes.

(from AJCC 8th Ed.) 